\title{
Evaluation of the hygienic-sanitary conditions of a dairy localized in the Island of São Luís, Maranhão
}

\section{Avaliação das condições higiênico-sanitárias de um laticínio localizado na Ilha de São Luís, Maranhão}

\author{
Rildon Porto Candeira * * (10) (orcid.org/0000-0002-0823-6283) \\ Lenka de Morais Lacerda' (1) (orcid.org/0000-0001-8746-9773) \\ Arlene dos Santos da Silva' ${ }^{1}$ (1) (orcid.org/0000-0002-4928-1304) \\ Lygia Silva Galeno' ${ }^{1}$ (i) (orcid.org/0000-0002-4431-7873) \\ Brenda Fernanda Sodré Moreno ${ }^{1}$ (i) (orcid.org/0000-0002-3076-1041) \\ Clarissa Costa Durães ${ }^{1}$ (1) (orcid.org/0000-0003-1152-8831)
}

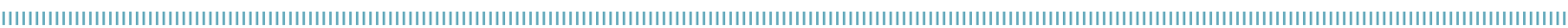

\begin{abstract}
The product quality is a competitive advantage that plays a differential role among companies. In the food industry, which is based on the Quality Management System, such as Good Manufacturing Practices (GMP), which cover the hygiene procedure, aiming at food safety. In view of the above, the aim of this study was to evaluate the hygienic-sanitary conditions of a selected dairy from the Sáo Luís Island - MA. An application of the checklist was performed, swab collection from the hands of the manipulators and equipment and the collection of water and yogurt for microbiological analysis. After this step, a training was performed for food handlers and finally, new collections and microbiological analysis were performed. All the microbiological analysis performed were satisfactory, except for the water sample, one before and again for training. It can be verified that the hygienic-sanitary condition of the dairy was good. However, after a lecture and new microbiological analyzes, improvements were observed in the results.
\end{abstract}

KEYWORDS: good manufacturing practices; microbiological quality; food safety.
RESUMO: A qualidade dos produtos é uma vantagem competitiva que desempenha um papel diferencial entre empresas. Na indústria alimentar, faz-se necessária a adoção do Sistema de Gestão de Qualidade, como as Boas Práticas de Fabricação (BPF), que abrangem os procedimentos essenciais de higiene, visando à segurança alimentar. Diante do exposto, objetivou-se avaliar as condiçóes higiênico-sanitárias de um laticínio selecionado da ilha de São Luís, Maranhão. Foi realizado um checklist, coleta por swabs das máos dos manipuladores e de equipamentos e coleta de água e iogurte para análises microbiológicas. Após essa etapa, foi executado um treinamento para os manipuladores de alimentos e, por fim, novas coletas e análises microbiológicas foram realizadas. Todas as análises microbiológicas realizadas mostraram-se satisfatórias, com exceção da amostra de água, uma antes e outra após o treinamento. Pode-se constatar que a condição higiênico-sanitária do laticínio era boa. Contudo, após uma palestra e a realização de novas análises microbiológicas, foram observadas melhorias nos resultados.

PALAVRAS-CHAVE: boas práticas de fabricação; qualidade microbiológica; segurança alimentar. 
Industries are continuously advancing to improve the quality of food, but even in highly qualified establishments, food contamination has been observed, demonstrating that, even with all the care and strict controls in food production, there may be pathogenic contamination (TONDO; BARTZ, 2011).

Within the food industries, the concern with food safety is evident, since these foods may be exposed to several hazards, such as contaminants, natural components, substances generated or included during manufacture, and mainly to microorganisms (ANVISA, 2013).

Given the above, the objective here was to evaluate the hygienic-sanitary conditions of a dairy product produced on the Island of São Luís, Maranhão, through microbiological analysis.

The study was carried out in 2016 on the Island of São Luís, Maranhão, also known as Upaon-Açu. A survey for operative dairy products was carried out on the island and then, a dairy specialized in the production of fruit-flavored whole yogurt was selected, sold in packaging in the forms of bottles and "pacifiers".

All techniques for preparing solutions, culture media, collection maneuvers, and microbiological analysis were performed in accordance with the Microbiological Food Analysis Methods Manual (SILVA et al., 2007).

After the first microbiological analysis of the samples, training was given to the handlers, which aimed to make them aware of the importance of following the requirements of Good Manufacturing Practices (GMP) to maintain the quality of dairy products.

Sample collection and microbiological analysis were carried out before and after training. Samples were collected during the production period in the industry and only the owner was aware of it, the handlers had no prior notice.

The surface smear technique was used, with swabs from the hands of the handlers working directly on the production line and the equipment used in the production process, in addition to collecting yogurt and water from various points of the site.

All samples were sent under refrigeration to the Food and Water Microbiology Laboratory at the State University of Maranhão (Universidade Estadual do Maranhão - UEMA), for the research of Escherichia coli, Staphylococcus sp., total coliforms and thermotolerant coliforms.

For the analysis of water, the interpretation of the results was carried out in accordance with Ordinance 2.914, of December $12^{\text {th }}, 2011$, of the Ministry of Health, which provides for the control and surveillance procedures of the quality of water for human consumption and its potability standard (BRASIL, 2011). Table 1 expresses the results obtained in the analysis.

In the first collection, samples $\mathrm{T} 1$ and $\mathrm{T} 3$ were satisfactory, while sample $\mathrm{T} 2$ showed unsatisfactory hygienic quality, as it did not meet the microbiological standards in force in Ordinance 2.914/2011, presenting a value of 2.0 MLN/100 $\mathrm{mL}$ for total coliforms.
The water used came from a well and was treated because of the dairy. The result indicated that, at some point, there was a hygienic-sanitary failure. According to Ordinance 2.914/2011, when samples with positive results for total coliforms are detected, corrective actions must be taken. Therefore, it was suggested to clean or change the tap and chlorinate the water.

In the second collection, it was observed that the problem found in sample T2 in the first collection was solved, presenting an index lower than 1.0 MPN/100 mL, which characterizes the sample as satisfactory for being within the legal limits.

Thus, samples T2 and T3 were satisfactory. However, a new problem was observed in sample $\mathrm{T} 1$, where an index of 2.0 MLN/100 mL was found for total coliforms, classifying it as unsatisfactory.

For the analysis of the handlers' hands, the interpretation of the results occurred in accordance with what is recommended by SILVA JÚNIOR (2002). Table 2 expresses the results obtained in the analysis.

All samples analyzed showed satisfactory hygienic-sanitary quality, as they met the proposed microbiological standards, despite variations in the values of total coliforms in samples M2 and M3 in the first collection. However, there is no recommended value for this parameter according to SILVA JÚNIOR (2002).

The results of the second collection show that the awareness work done in conjunction with the handlers was very useful, since all samples were free from contamination, showing that hand hygiene was being done correctly.

For the analysis of the surface equipment, the interpretation of results was performed according to the recommended by SILVA JÚNIOR (2002). Table 3 expresses the results obtained in the analysis.

Table 1. Most likely number of total coliforms and $E$. coli from water analysis.

\begin{tabular}{|c|c|c|c|}
\hline \multirow{2}{*}{ Microorganisms } & \multicolumn{3}{|c|}{ Water samples } \\
\hline & $\mathrm{T} 1$ *2 & $\mathrm{T} 2 * 3$ & $T 3 * 4$ \\
\hline \multicolumn{4}{|l|}{ Before training } \\
\hline $\begin{array}{l}\mathrm{MLN} / \mathrm{mL} \text { of } \\
\text { total coliforms }\end{array}$ & $\begin{array}{c}<1.0 \\
(\text { absence })^{* 1}\end{array}$ & $<2.0$ & $\begin{array}{c}<1.0 \\
\text { (absence)*1 }^{*}\end{array}$ \\
\hline $\begin{array}{l}\text { MLN/mL of } \\
\text { Escherichia coli }\end{array}$ & $\begin{array}{c}<1.0 \\
(\text { absence })^{* 1}\end{array}$ & $\begin{array}{c}<1.0 \\
(\text { absence)*1 }\end{array}$ & $\begin{array}{c}<1.0 \\
\text { (absence)*1 }^{*}\end{array}$ \\
\hline \multicolumn{4}{|l|}{ After training } \\
\hline $\begin{array}{l}\text { MLN/mL of } \\
\text { Total coliforms }\end{array}$ & $<2.0$ & $\begin{array}{c}<1.0 \\
(\text { absence)*1 }\end{array}$ & $\begin{array}{c}<1.0 \\
\text { (absence)*1 }^{*}\end{array}$ \\
\hline $\begin{array}{l}\mathrm{MLN} / \mathrm{mL} \text { of } \\
\text { Escherichia coli }\end{array}$ & $\begin{array}{c}<1.0 \\
(\text { absence) })^{\star 1}\end{array}$ & $\begin{array}{c}<1.0 \\
\left(\text { absence) }{ }^{\star 1}\right.\end{array}$ & $\begin{array}{c}<1.0 \\
\text { (absence)*1 }^{*}\end{array}$ \\
\hline
\end{tabular}

*1 standard: <1.0; MLN/ $100 \mathrm{~mL}$ (absence) according to Ordinance 2.914, of December $12^{\text {th }}, 2011$ from the Ministry of Health; ${ }^{* 2}$ T1: "pacifier" taps; ${ }^{* 3}$ T2: internal sanitation tap; ${ }^{* 4}$ T3: external sanitation tap; MLN: most likely number. 
Table 2. Most likely number of total coliforms and $E$. coli and research of Staphylococcus sp. for analysis of the hands of handlers.

\begin{tabular}{|c|c|c|c|}
\hline \multirow{2}{*}{ Microorganisms } & \multicolumn{3}{|c|}{ Hand samples } \\
\hline & $M 1 * 2$ & $M 2 * 3$ & $M 3 * 4$ \\
\hline \multicolumn{4}{|l|}{ Before training } \\
\hline $\mathrm{NMP} / \mathrm{cm}^{2}$ of total coliforms & $<3.0$ & $<9.1$ & $<23.0$ \\
\hline $\begin{array}{l}\mathrm{NMP} / \mathrm{cm}^{2} \text { of thermotolerant } \\
\text { coliforms }\end{array}$ & $<3.0^{* 1}$ & $<3.0^{* 1}$ & $<3.0^{* 1}$ \\
\hline $\begin{array}{l}\text { Staphylococcus sp. and coagulase } \\
\text { positive Staphylococcus research }\end{array}$ & $\begin{array}{l}<10 \text { UFC/g and negative for } \\
\text { coagulase testing }\end{array}$ & $\begin{array}{l}<10 \text { UFC/g and negative for } \\
\text { coagulase testing }\end{array}$ & $\begin{array}{l}<10 \text { UFC/g and negative for } \\
\text { coagulase testing }\end{array}$ \\
\hline \multicolumn{4}{|l|}{ After training } \\
\hline $\mathrm{MLN} / \mathrm{cm}^{2}$ of total coliforms & $<3.0$ & $<3.0$ & $<3.0$ \\
\hline $\begin{array}{l}\mathrm{MLN} / \mathrm{cm}^{2} \text { of thermotolerant } \\
\text { coliforms }\end{array}$ & $<3.0^{* 1}$ & $<3.0^{* 1}$ & $<3.0^{* 1}$ \\
\hline $\begin{array}{l}\text { Staphylococcus sp. and coagulase } \\
\text { positive Staphylococcus research }\end{array}$ & $\begin{array}{l}<10 \text { UFC/g and negative for } \\
\text { coagulase testing }\end{array}$ & $\begin{array}{l}<10 \text { UFC/g and negative for } \\
\text { coagulase testing }\end{array}$ & $\begin{array}{l}<10 \text { UFC/g and negative for } \\
\text { coagulase testing }\end{array}$ \\
\hline
\end{tabular}

*1 standard: <3.0; MLN/50 cm² (absence) according to SILVA JÚNIOR (2002); ${ }^{* 2} \mathbf{M} 1$ : handler 1; ${ }^{* 3}$ M2: handler 2; ${ }^{* 4}$ M3: handler 3; MLN: most likely number.

Table 3. Most likely number of total coliforms and $E$. coli and research of Staphylococcus sp. from the analysis of the equipment surface.

\begin{tabular}{|c|c|c|c|}
\hline \multirow{2}{*}{ Microorganisms } & \multicolumn{3}{|c|}{ Equipment surface samples } \\
\hline & $\mathrm{S} 1 * 2$ & $\mathrm{~S} 2 * 3$ & $53 * 4$ \\
\hline \multicolumn{4}{|l|}{ Before training } \\
\hline $\mathrm{MLN} / \mathrm{cm}^{2}$ of total coliforms & 29.0 & 9.1 & 23.0 \\
\hline $\begin{array}{l}\mathrm{MLN} / \mathrm{cm}^{2} \text { of thermotolerant } \\
\text { coliforms }\end{array}$ & $<3.0^{* 1}$ & $<3.0 * 1$ & $<3.0^{* 1}$ \\
\hline $\begin{array}{l}\text { Staphylococcus sp. and coagulase } \\
\text { positive Staphylococcus research }\end{array}$ & $\begin{array}{l}<10 \text { UFC } / \mathrm{cm}^{2} \text { and negative } \\
\text { for coagulase testing }\end{array}$ & $\begin{array}{l}<10 \text { UFC } / \mathrm{cm}^{2} \text { and negative } \\
\text { for coagulase testing }\end{array}$ & $\begin{array}{l}<10 \text { UFC } / \mathrm{cm}^{2} \text { and negative } \\
\text { for coagulase testing }\end{array}$ \\
\hline \multicolumn{4}{|l|}{ After training } \\
\hline $\mathrm{MLN} / \mathrm{cm}^{2}$ of total coliforms & $<3.0$ & $<23.0$ & $<3.0$ \\
\hline $\begin{array}{l}\mathrm{MLN} / \mathrm{cm}^{2} \text { of thermotolerant } \\
\text { coliforms }\end{array}$ & $<3.0 * 1$ & $<3.0^{* 1}$ & $<3.0^{* 1}$ \\
\hline $\begin{array}{l}\text { Staphylococcus sp. and coagulase } \\
\text { positive Staphylococcus research }\end{array}$ & $\begin{array}{l}<10 \text { UFC } / \mathrm{cm}^{2} \text { and negative } \\
\text { for coagulase testing }\end{array}$ & $\begin{array}{l}<10 \text { UFC } / \mathrm{cm}^{2} \text { and negative } \\
\text { for coagulase testing }\end{array}$ & $\begin{array}{l}<10 \text { UFC } / \mathrm{cm}^{2} \text { and negative } \\
\text { for coagulase testing }\end{array}$ \\
\hline
\end{tabular}

*1 standard: <3.0; MLN/50 $\mathrm{cm}^{2}$ (absence) according to SILVA JÚNIOR (2002); ${ }^{* 2}$ S1: "pacifier" table 1; *3 S2: "pacifier" table 2; ${ }^{* 4}$ S3: labeling table 3; MLN: most likely number.

All samples analyzed showed satisfactory hygienic-sanitary quality, as they met the proposed microbiological standards, despite variations in the values of total coliforms. However, there is no recommended value for this according to SILVA JÚNIOR (2002). The variations in the values of total coliforms indicated that the cleaning of the surfaces was not occurring effectively, and more efficient cleaning measures should be implemented.

An increase was observed in total coliforms in the second collection. The increase in total coliforms in the sample S2 can be explained by relating it to the T1 sample of the water. Sample T1 presented above the allowed value for total coliforms. This water was spilled on the surface of the "pacifier" table, which was sample S2. Thus, contamination of the surface probably occurred from there.

For the analysis of yogurt, the interpretation of the results occurred according to the parameters recommended in RDC No. 12 (item 8. f, point b) of January $2^{\text {nd }}, 2001$ by ANVISA (ANVISA, 2013). Table 4 expresses the results obtained in the analysis. 
Table 4. Most likely number of total coliforms and E. coli and research of Staphylococcus sp. in yogurt.

\begin{tabular}{|c|c|c|c|}
\hline \multirow{2}{*}{ Microorganisms } & \multicolumn{3}{|c|}{ Yogurt samples } \\
\hline & $11 * 2$ & $12 * 3$ & $13 * 4$ \\
\hline \multicolumn{4}{|l|}{ Before training } \\
\hline $\mathrm{MLN} / \mathrm{cm}^{2}$ of total coliforms & $<3.0$ & $<3.0$ & $<3.0$ \\
\hline $\begin{array}{l}\mathrm{MLN} / \mathrm{cm}^{2} \text { of thermotolerant } \\
\text { coliforms }\end{array}$ & $<3.0 * 1$ & $<3.0 * 1$ & $<3.0^{* 1}$ \\
\hline $\begin{array}{l}\text { Staphylococcus sp. and coagulase } \\
\text { positive Staphylococcus research }\end{array}$ & $\begin{array}{l}<10 \text { UFC/g and negative for } \\
\text { coagulase testing }\end{array}$ & $\begin{array}{c}<10 \text { UFC/g and negative for } \\
\text { coagulase testing }\end{array}$ & $\begin{array}{l}<10 \text { UFC/g and negative for } \\
\text { coagulase testing }\end{array}$ \\
\hline \multicolumn{4}{|l|}{ After training } \\
\hline $\mathrm{MLN} / \mathrm{cm}^{2}$ of total coliforms & $<3.0$ & $<3.0$ & $<3.0$ \\
\hline $\begin{array}{l}\mathrm{MLN} / \mathrm{cm}^{2} \text { of thermotolerant } \\
\text { coliforms }\end{array}$ & $<3.0 * 1$ & $<3.0 * 1$ & $<3.0^{* 1}$ \\
\hline $\begin{array}{l}\text { Staphylococcus sp. and coagulase } \\
\text { positive Staphylococcus research }\end{array}$ & $\begin{array}{l}<10 \text { UFC/g and negative for } \\
\text { coagulase testing }\end{array}$ & $\begin{array}{l}<10 \text { UFC/g and negative for } \\
\text { coagulase testing }\end{array}$ & $\begin{array}{c}<10 \text { UFC/g and negative for } \\
\text { coagulase testing }\end{array}$ \\
\hline
\end{tabular}

${ }^{* 1}$ standard: <3.0; MLN/g (absence) according to RDC No.12 (item 8. f, point b) of January $2^{\text {nd }}, 2001$ from ANVISA; *2 I1: yogurt 1; *3 I2: yogurt 2; *4 I3: yogurt 3; MLN: most likely number.

The samples analyzed in the two collections showed satisfactory hygienic-sanitary quality, meeting the microbiological standards in force according to RDC No. 12/2001. The results are positive, as they point out that the yogurt is being produced in good hygienic conditions.

It was verified that the handlers had good hygienic conduct, dressed their uniforms correctly, and did not wear adornments. However, it was observed that one of the handlers had long nails, which is worrisome because, according to POTTER; PERRY (2013), large nails increase the number of bacteria residing in this area of the body.

According to the results verified in the dairy water samples, the $\mathrm{T} 1$ sample problem can be explained due to possible contamination in the tap by inadequate hygiene, since the dairy water source was the same for all taps. Again, cleaning or changing the tap and chlorination of the water was suggested, in addition to the need to repeat the analysis after adopting corrective measures.

The results of the MLN of Total Coliforms and E. coli and a survey of Staphylococcus sp. from the analysis of the hands of handlers before training were different from those found by PONATH et al. (2016), who, when analyzing the hands of food handlers in the Municipality of Ji-Paraná, Rondônia, found unsatisfactory rates for all microorganisms analyzed, including total coliforms and Staphylococcus.

Results of the microbiological analysis of the equipment surfaces were similar to those obtained by ZANON; PAGNAN (2012), who worked in a Food and Nutrition Unit (FNU) analyzing utensils and surfaces, and made collections before and after the beginning of activities. The results of all samples were satisfactory, both in the first and in the second collection.

NUNES et al. (2013), when analyzing 3 samples of yogurt from supermarkets, also proved the absence of total coliforms and thermotolerant coliforms.

The training provided to handlers and owners was an important step in the research, since this was the moment when the failures found in the facility were exposed, as well as their solutions, and information on the production of safe food, emphasizing the hygiene issue.

The efficiency that the elements passed on to the listeners was observed during the last visit and, mainly, through the results of the last microbiological analysis. The analysis of the hand samples was the most relevant result, as it was observed that there was no contamination of the samples collected after the lecture.

The microbiological analyses allowed to evaluate the hygienic-sanitary condition of the dairy. Most of the microbiological parameters were classified as satisfactory, although there were still points to be improved.

The training provided a positive contribution to the dairy community, expanding and renewing the knowledge of the handlers. In addition, it can be observed that in almost all samples that showed some kind of variation in the values in the first collection, they were absent in the second, just after the lecture.

Thus, there was an improvement in the quality and safety of the dairy products produced. However, it is necessary that continuous improvements are applied in this type of establishment, so that these industries achieve more prominence, expanding their market and ensuring total customer satisfaction. 
ACKNOWLED GEMENTS: The main author would like to thank the Universidade Estadual do Maranhão for the scholarship.

FUNDING: This study did not receive any specific grant from funding agencies in the public, commercial, or not-for-profit sectors.

CONFLICTS OF INTEREST: All authors declare that they have no conflict of interest.

ETHICAL APPROVAL: Not applicable.

AVAILABILITY OF DATA AND MATERIAL: All data generated or analyzed during this study are included in this published article.

AUTHORS' CONTRIBUTIONS: Conceptualization: CANDEIRA, R.P.; MORENO, B.F.S.; GALENO, L.S.; SILVA, A.S.

Data curation: CANDEIRA, R.P.; SILVA, A.S.; LACERDA, L.M. Methodology: CANDEIRA, R.P.; GALENO, L.S.; MORENO, B.F.S.; DURAES, C.C. Project administration: CANDEIRA, R.P.; SILVA, A.S. Supervision: SILVA, A.S.; LACERDA, L.M. Writing - original draft: CANDEIRA, R.P.; LACERDA, L.M. Writing — review \& editing: CANDEIRA, R.P.; LACERDA, L.M.

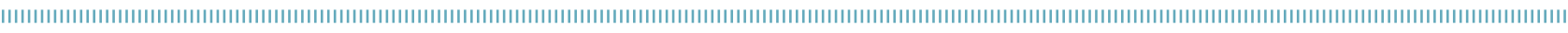

\section{REFERENCES}

AGÊNCIA NACIONAL DE VIGILÂNCIA SANITÁRIA (ANVISA). Guia para Comprovação da Segurança de Alimentos e Ingredientes. 2013. Available from: https://alimentosprocessados.com.br/arquivos/ Seguranca-e-qualidade-dos-alimentos/Guia-para-Comprovacaoda-Seguranca-de-Alimentos-e-Ingredientes-ANVISA.pdf. Access on: Sep. 202018.

BRASIL. Ministério da Saúde. Portaria ${ }^{\circ} 2914$, de 12 de dezembro de 2011 . Dispõe sobre os procedimentos de controle e de vigilância da qualidade da água para consumo humano e seu padrão de potabilidade. Available from: http://site.sabesp.com.br/site/ uploads/file/asabesp_doctos/PortariaMS291412122011.pdf. Access on: Sep. 212018.

NUNES, C.R.Z.; SILVA, M.L.; BORTOLUZZI, M. Análise microbiológica e físico-sensorial de iogurtes sabor ameixa comercializados na região oeste do Paraná. 2013. Available from: http://repositorio.roca.utfpr. edu.br/jspui/bitstream/1/1100/1/MD_COALM_2012_2_01. pdf. Access on: Sep. 232018.

PONATH, F.S.; VALIATTI, T.B.; SOBRAL, F.O.S.; ROMÃO, N.F.; ALVES, G.M.C.; PASSONI, G.P. Avaliação da higienização das mãos de manipuladores de alimentos do Município de Ji-Paraná, Estado de Rondônia, Brasil. Revista Pan-Amazônica de Saúde, v.7, n.1, p.63-69, 2016. http://dx.doi.org/10.5123/ s2176-62232016000100008

POTTER, P.A; PERRY, A.G. Fundamentos de Enfermagem. 8.ed. São Paulo: Santos. Elsevier, 2013. 1424p.

SILVA JÚNIOR, E.A. Manual de Controle Higiênico-Sanitário em Alimentos. 5.ed. São Paulo: Ed. Varela, 2002. 397p.

SILVA, N.; JUNQUEIRA, V.C.A.; SILVEIRA, N.F. de A.; TANIWAKI, M.H.; SANTOS, R.F.S. dos; GOMES, R.A.R. Manual de métodos de análise microbiológica de alimentos. 3.ed. São Paulo: Varela, 2007. 536p.

TONDO, E.C.; BARTZ, S. Microbiologia e sistemas de gestão da segurança de alimentos. Porto Alegre, RS: Sulina, 2011.

ZANON, A.C.M; PAGNAN, M.F. Análise microbiológica de utensílios e superfícies de uma unidade de alimentação e nutrição da cidade de Arapongas - PR. 2012. Available from: https:// docplayer.com.br/22277004-Analise-microbiologica-deutensilios-e-superficies-de-uma-unidade-de-alimentacaoe-nutricao-da-cidade-de-arapongas-pr.html. Access on: Sep. 232018. 